\title{
Cdk5/p35 Regulates Neurotransmitter Release through Phosphorylation and Downregulation of P/Q-Type Voltage-Dependent Calcium Channel Activity
}

\author{
Kazuhito Tomizawa, ${ }^{1}$ Jun Ohta, ${ }^{2}$ Masayuki Matsushita, ${ }^{1}$ Akiyoshi Moriwaki, ${ }^{1}$ Sheng-Tian Li, ${ }^{1}$ Kohji Takei, ${ }^{3}$ \\ and Hideki Matsui ${ }^{1}$ \\ Departments of ${ }^{1}$ Physiology, ${ }^{2 B}$ Biochemistry, and ${ }^{3}$ Neuroscience, Okayama University Graduate School of Medicine and \\ Dentistry, Okayama 700-8558, Japan
}

Cyclin-dependent kinase 5 (Cdk5) is a proline-directed serine/ threonine kinase with close structural homology to the mitotic Cdks. The complex of Cdk5 and p35, the neuron-specific regulatory subunit of Cdk5, plays important roles in brain development, such as neuronal migration and neurite outgrowth. Moreover, Cdk5 is thought to be involved in the promotion of neurodegeneration in Alzheimer's disease.

Cdk5 is abundant in mature neurons; however, its physiological functions in the adult brain are unknown. Here we show that Cdk5/p35 regulates neurotransmitter release in the presynaptic terminal. Both Cdk5 and p35 were abundant in the synaptosomes. Roscovitine, a specific inhibitor of Cdk5 in neurons, induced neurotransmitter release from the synaptosomes in response to membrane depolarization and enhanced the EPSP slopes in rat hippocampal slices. The electrophysiological study using each specific inhibitor of the voltage-dependent

Cdk5 is a serine/threonine kinase with close structural homology to the Cdks (Lew and Wang, 1995). Cdk5 forms a complex with its activators, p35 nck5a $(p 35)$ or p39 nck5ai (p39), in neurons (Lew et al., 1994; Tsai et al., 1994; Tang et al., 1995). The association of Cdk5 with its activators is essential for the kinase activation (Lew et al., 1994; Tsai et al., 1994; Tang et al., 1995). Previous studies have shown that the complex of $\mathrm{Cdk} 5$ and p35 has multiple functions in neurons. Mice lacking p35 display defects in cortical and hippocampal lamination as well as fasciculation of the axon fibers (Chae et al., 1997). In the cortex of p35 knock-out mice, the layering of cortical neurons is inverted, because neurons born later cannot migrate past their predecessors (Chae et al., 1997). Inactivation of $\mathrm{Cdk} 5$ in cultured cortical or cerebellar neurons inhibits neurite outgrowth (Nikolic et al., 1996). Cdk5 kinase activity and p35 expression level are most prominent from newborn to 2 weeks after birth, when synaptogenesis occurs through the development of the rat brain (Matsushita et al., 1996; Tomizawa et al., 1996). Moreover, Cdk5 kinase activity increases in the kindling rat hippocampus, in which sprouting and synaptic reor-

Received Oct. 31, 2001; revised Jan. 23, 2002; accepted Jan. 23, 2002.

This work was supported by a Grant-in-Aid for Scientific Research from the Ministry of Education, Science, Sports and Culture of Japan and by Industrial Technology Research Grant Program in '01 from New Energy and Industrial Technology Development Organization, Japan. We are grateful to Dr. L. Meijer for roscovitine and to Dr. A. Nairn for CaM KI antibodies.

Correspondence should be addressed to Kazuhito Tomizawa, Department of Physiology, Okayama University Graduate School of Medicine and Dentistry, Shikata-cho 2-5-1, Okayama 700-8558, Japan. E-mail: tomikt@md.okayama-u.ac.jp. Copyright (C) 2002 Society for Neuroscience $0270-6474 / 02 / 222590-08 \$ 15.00 / 0$ calcium channels (VDCCs) and calcium imaging revealed that roscovitine enhanced $\mathrm{Ca}^{2+}$ influx from the P/Q-type VDCC. Moreover, Cdk5/p25 phosphorylated the intracellular loop connecting domains II and III ( $\left.\mathrm{L}_{\mathrm{II}-\mathrm{III}}\right)$ between amino acid residues 724 and 981 of isoforms cloned from rat brain of the $\alpha_{1 \mathrm{~A}}$ subunit of $\mathrm{P} / \mathrm{Q}$-type $\mathrm{Ca}^{2+}$ channels. The phosphorylation inhibited the interaction of $\mathrm{L}_{\mathrm{II}-\mathrm{III}}$ with SNAP-25 and synaptotagmin I, which were plasma membrane soluble $\mathrm{N}$-ethylmaleimide-sensitive factor attachment protein (SNAP) receptor (SNARE) proteins and were required for efficient neurotransmitter release. These results strongly suggest that Cdk5/p35 inhibits neurotransmitter release through the phosphorylation of P/Q-type VDCC and downregulation of the channel activity.

Key words: Cdk5; presynapse; calcium channel; SNARE; p35; exocytosis

ganization have also been observed (Stula et al., 1988; Moriwaki et al., 1996; Tomizawa et al., 2000). These previous data suggest that $\mathrm{Cdk} 5 / \mathrm{p} 35$ play critical roles in neural migration, differentiation, and synaptogenesis in immature neurons.

Recent studies have shown that $\mathrm{Cdk} 5 / \mathrm{p} 35$ is involved in neuronal degeneration in Alzheimer's brain (Patrick et al., 1999; Lee et al., 2000). Proteolytic cleavage of p35 produces p25, which accumulates in the brains of patients with Alzheimer's disease. The calpain-dependent proteolytic cleavage causes prolonged activation and mislocalization of $\mathrm{Cdk} 5$. Consequently, the $\mathrm{Cdk} 5$ / p25 kinase hyperphosphorylates tau proteins, disrupts the cytoskeleton, and promotes neuronal cell death.

These previous data suggest that $\mathrm{Cdk} 5 / \mathrm{p} 35$ plays important roles in the immature and aging brain. However, Cdk5 expression is most prominent in mature neurons (Matsushita et al., 1996). The physiological function of $\mathrm{Cdk} 5 / \mathrm{p} 35$ in the mature neuron is not clear. Previous studies have shown that Cdk5 is strongly expressed in axons of the adult brain (Tsai et al., 1993; Matsushita et al., 1996). Several studies have identified Munc 18 (nSec-1) (Shuang et al., 1998), Synapsin 1 (Jovanovic et al., 1996; Matsubara et al., 1996), and Amphiphysin I (Floyd et al., 2001) as physiological substrates of $\mathrm{Cdk} 5$. These proteins localize in the presynaptic terminal of the mature neuron and play important roles in neurotransmitter release. These previous observations lead to a hypothesis that $\mathrm{Cdk} 5 / \mathrm{p} 35$ may regulate neurotransmitter release.

Neurotransmitter release from specialized active zones in presynaptic terminals is a critical step in synaptic transmission. Release of synaptic vesicles containing neurotransmitter is trig- 
gered by an influx of $\mathrm{Ca}^{2+}$ through voltage-dependent calcium channels (VDCCs) (Catterall, 1998). It has been thought that N-type and P/Q-type VDCCs mainly regulate neurotransmitter release in the presynaptic terminals (Wheeler et al., 1996; Reid et al., 1997). Specific protein-protein interactions between a synaptic protein interaction (synprint) site on N-type and $\mathrm{P} / \mathrm{Q}$-type channels and the presynaptic soluble $N$-ethylmaleimide-sensitive factor attachment protein (SNAP) receptor (SNARE) proteins, syntaxin, SNAP-25, and synaptotagmin are required for efficient synchronous neurotransmitter release (Kim and Catterall, 1997; Catterall, 1998). The synprint sites on N-type and P/Q-type $\mathrm{Ca}^{2+}$ channels locate within the intracellular loop connecting homologous domains II and III ( $\left.\mathrm{L}_{\mathrm{II}-\mathrm{III}}\right)$ of their $\alpha_{1 \mathrm{~A}}$ and $\alpha_{1 \mathrm{~B}}$ subunits (Catterall, 1998). The interaction of $\mathrm{N}$-type $\mathrm{Ca}^{2+}$ channels with syntaxin and SNAP-25 is $\mathrm{Ca}^{2+}$ dependent and regulated by protein phosphorylation (Yokoyama et al., 1997). In this study, we demonstrate direct evidence that $\mathrm{Cdk} 5 / \mathrm{p} 35$ regulates neurotransmitter release through the phosphorylation of the $\mathrm{L}_{\mathrm{II}-\mathrm{III}}$ of P/Q-type VDCC.

\section{MATERIALS AND METHODS}

Electrophysiological recording. Field EPSP recording was performed as described previously (Lu et al., 1996, 1999). Briefly, male Wistar rats aged 7-8 weeks were killed in accordance with the guidelines of the Health Science Division of the Graduate School of Medicine and Dentistry, Okayama University. The brain was quickly removed and immersed in ice-cold artificial CSF (ACSF) bubbled with a gas mixture of $95 \% \mathrm{O}_{2}$ and $5 \% \mathrm{CO}_{2}$. The hippocampus was dissected, and $400 \mu \mathrm{m}$ transverse slices were prepared. The hippocampal slices were incubated in an interface-recording chamber maintained at $28^{\circ} \mathrm{C}$ for at least $1.5 \mathrm{hr}$ before recording and were constantly subf used with gas-saturated ACSF at $1.2 \mathrm{ml} / \mathrm{min}$. The composition of the ACSF was as follows (in mM): $\mathrm{NaCl} 124, \mathrm{KCl} 4.4, \mathrm{CaCl}_{2} 2.5, \mathrm{MgSO}_{4} 1.3, \mathrm{NaH}_{2} \mathrm{PO}_{4} 1, \mathrm{NaHCO}_{3} 26$, and glucose 10 .

To record the field EPSPs, a glass micropipette filled with ACSF (1-5 $\mathrm{M} \Omega$ resistance) was placed in the stratum radiatum of the CA1 region, and a bipolar stimulating electrode was placed along the Schaffer collateral fibers. The intensity of the stimulation was adjusted to produce an EPSP with a slope between 35 and $50 \%$ of the maximum. The test stimulation was delivered once per minute $(0.017 \mathrm{~Hz})$.

The following drugs were used. Roscovitine was kindly donated by L. Meijer (Station Biologique, Bretagne, France); olomoucine, $\omega$-Conotoxin GVIA ( $\omega$-CgTX GVIA), $\omega$-Agatoxin IVA ( $\omega$-Aga IVA), and Nifedipine were from RBI (Natick, MA). The drugs were prepared as stock solutions and diluted in ACSF immediately before application. Roscovitine, olomoucine, and Nifedipine were prepared in DMSO, and $\omega$-CgTX GVIA and $\omega$-Aga IVA were dissolved in $\mathrm{H}_{2} \mathrm{O}$. The final concentration of the DMSO was $0.1 \%$.

Data are shown as mean $( \pm$ SEM $)$ percentage of the baseline EPSP slope. Data were analyzed using either the Student $t$ test to compare the two conditions or ANOVA followed by planned comparisons of the multiple conditions, and $p<0.05$ was considered significant.

Synaptosome preparation and Western blot analysis. Synaptic fractions were prepared from rat brain as described previously (Huttner et al., 1983) with minor modifications. Briefly, the brains from seven male Wistar rats were homogenized in $50 \mathrm{ml}$ of sucrose buffer $(0.32 \mathrm{M} \mathrm{su}-$ crose $/ 5 \mathrm{~mm}$ HEPES/KOH buffer, $\mathrm{pH} 7.4$, containing the following protease inhibitors: $0.4 \mathrm{~mm}$ phenylmethylsulfonyl fluoride, $0.8 \mathrm{mg} / \mathrm{ml} \mathrm{pep-}$ statin A, $0.8 \mathrm{mg} / \mathrm{ml}$ antipain, $0.8 \mathrm{mg} / \mathrm{ml}$ leupeptin, $0.8 \mathrm{mg} / \mathrm{ml}$ benzamidine, $0.4 \mathrm{mg} / \mathrm{ml}$ aprotinin). The homogenate was spun for $10 \mathrm{~min}$ at $800 \times g$, yielding a pellet $(\mathrm{P} 1)$. The supernatant was centrifuged for 15 min at $9200 \times g$. The resulting pellet was washed once with sucrose buffer, yielding a crude synaptosomal pellet $\left(\mathrm{P} 2^{\prime}\right)$. The supernatant was centrifuged at $165,000 \times g$ for $2 \mathrm{hr}$, yielding a pellet (P3) and supernatant (S3). P2' was resuspended in $4 \mathrm{ml}$ of sucrose buffer and lysed by the addition of 9 vol of distilled water, followed by homogenization. HEPES/ $\mathrm{KOH}$ buffer, $\mathrm{pH} 7.4$, was added to a final concentration of $10 \mathrm{~mm}$ together with the above protease inhibitors. The fraction was spun at $25,000 \times g$ for $20 \mathrm{~min}$ (pellet LP1) and the supernatant (LS1) was further centrifuged for $2 \mathrm{hr}$ at $165,000 \times \mathrm{g}$, yielding a crude synaptic vesicle pellet (LP2) and a supernatant (LS2).
Western blot analysis was performed at high stringency, essentially as described previously (Tomizawa et al., 1996). Briefly, $50 \mu \mathrm{g}$ of each fraction protein was separated by electrophoresis through a $10-12 \%$ SDS-PAGE gel before transfer to a nitrocellulose membrane (Amersham Biosciences). Blots were probed with primary antibodies against $\mathrm{Cdk} 5$ (C-8; Santa Cruz Biotechnology, Santa Cruz, CA), p35 ${ }^{\text {nck5a }}$ (N-20; Santa Cruz Biotechnology), synaptophysin (Progen Biotechnik, Heidelberg, Germany), and calmodulin kinase I (kindly provided by A. C. Nairn, The Rockefeller University, New York, NY), and secondary antibodies [antirabbit $\operatorname{IgG}(\mathrm{H}+\mathrm{L})$, Pierce, Rockford, IL] before bands were visualized using a commercial ECL detection kit (Amersham Biosciences).

Measurement of glutamate release from synaptosome. The purified synaptosomes were preincubated at $37^{\circ} \mathrm{C}$ with each concentration of roscovitine or DMSO (final concentration, $0.1 \%$ ) as controls for $30 \mathrm{~min}$. Then $1 \mathrm{~mm} \mathrm{NADP}^{+}, 60 \mathrm{U}$ glutamate dehydrogenase (GDH), and $1.3 \mathrm{~mm}$ $\mathrm{CaCl}_{2}$ were added, and the synaptosomes were further incubated for 10 min. The suspension was then transferred to a stirred cuvette in the fluorescence spectrophotometer, and $1 \mathrm{mM}$ 4-aminopyridine (4-AP; Sigma, St. Louis, MO) was added in solution to depolarize the cell membrane. When glutamate is oxidized to 2-oxoglutarate by GDH and $\mathrm{NADP}^{+}, \mathrm{NADP}^{+}$is reduced to NADPH, and the fluorescence of NADPH can be measured (Vinje et al., 1999). Internal standards were made by adding 2 nmol glutamate at the end of each assay.

$\mathrm{Ca}^{2+}$-imaging experiments. For the $\mathrm{Ca}^{2+}$ imaging, the rat hippocampal cultures were prepared as described previously (Yan et al., 1999). The cells were plated on glass-bottom dishes (Iwaki, Tokyo, Japan) and maintained for 2 weeks. After 2 weeks of culture, the medium was changed to ACSF with $10 \mathrm{mM}$ HEPES, pH 7.4, and the cells were then loaded with $5 \mu \mathrm{M}$ fura- $2 \mathrm{AM}$ for $40 \mathrm{~min}$ at room temperature. Then cells were washed with ACSF and incubated with $25 \mu \mathrm{M} \mathrm{AP5,} 0.5 \mu \mathrm{M} \omega$-CgTx GVIA, and $10 \mu \mathrm{M}$ Nifedipine, with or without $5 \mu \mathrm{M}$ roscovitine to measure $\mathrm{Ca}^{2+}$ entry from the P/Q-type VDCC channels for $30 \mathrm{~min}$ at $37^{\circ} \mathrm{C}$. The cells were directly exposed to $50 \mathrm{~mm} \mathrm{KCl}$ for $10 \mathrm{sec}$ by a gravity-fed "sewer pipe" system (Yan et al., 1999), and fura-2 AM fluorescence was recorded using a video image analysis system (AquaCosmos, Hamamatsu Photonics, Hamamatsu, Japan), with excitation alternatively at 340 and $380 \mathrm{~nm}$, and emission at $510 \mathrm{~nm}$. Data from 20-30 individual cells were collected per experiment, and ensemble averages were calculated for multiple experiments. Data acquisition was typically at $5 \mathrm{sec}$ intervals and lasted for $10 \mathrm{~min}$.

Phosphorylation and binding assay. Complementary DNA encoding $\mathrm{L}_{\text {II-III }}$ (amino acids 724-983) of isoforms cloned from rat brain (rbA) of the $\alpha_{1 \mathrm{~A}}$ subunit of $\mathrm{P} / \mathrm{Q}$-type $\mathrm{Ca}^{2+}$ channel was cloned from a rat hippocampus cDNA library (Stratagene, La Jolla, CA) by PCR with oligonucleotides 5'-GAACTCACCAAGGATGAACAAG-3' and 5'TCTGCGCTCCCTGTCATCGTG-3'. The PCR products were subcloned into PCR-Blunt II-TOPO vector, and the sequence was confirmed. Then, the PCR products were cleaved with Bam HI and XhoI and ligated into pGEX-6P (Amersham Biosciences).

Glutathione $S$-transferase (GST)-tagged proteins were expressed and purified as described previously (Lee et al., 1996). Finally, GST-fusion proteins were dialyzed with phosphate buffer. Phosphorylation reactions were performed in a basal buffer containing $20 \mathrm{~mm}$ MOPS, $\mathrm{pH} 7.4,30 \mathrm{~mm}$ $\mathrm{MgCl}_{2}, 100 \mu \mathrm{M}\left[\gamma^{-}{ }^{32} \mathrm{P}\right]$ ATP $(300 \mathrm{dpm} / \mathrm{pmol})$, and $1 \mathrm{~mm}$ dithiothreitol. GST-L $\mathrm{L}_{\text {II-III }}$ was incubated with each concentration of GST-Cdk5 and/or GST-p25 at $32^{\circ} \mathrm{C}$ for $30 \mathrm{~min}$.

For phosphorylation time course experiments, $1 \mu \mathrm{M}$ GST- $\mathrm{L}_{\mathrm{II}-\mathrm{III}}$ was incubated with both $2 \mu \mathrm{M}$ GST-Cdk5 and GST-p 25 at $32^{\circ} \mathrm{C}$. Additional $\left[\gamma_{-}{ }^{32} \mathrm{P}\right]$ ATP, GST-Cdk5, and GST-p25 were added to the time course reactions at $60 \mathrm{~min}$ to test whether these reagents were limiting the maximal incorporation. The reactions were terminated by the addition of boiling SDS sample buffer. After SDS-PAGE, gel drying, and autoradiography, the relevant gel slices were excised and Cerenkov-counted to determine total ${ }^{32} \mathrm{P}$ incorporation. Specific radioactivity in picomoles of $\left[\gamma^{-32} \mathrm{P}\right]$ ATP was determined by counting diluted aliquots of the stock, and this conversion value was used to calculate moles of ${ }^{32} \mathrm{P}$ incorporated and the molar ratio of ${ }^{32} \mathrm{P}$ to $\mathrm{GST}-\mathrm{L}_{\mathrm{II}-\mathrm{III}}$.

For binding assay, GST- $\mathrm{L}_{\text {II-III }}$ proteins were incubated with purified bovine Cdk5/p25 (Lee et al., 1996) and/or $5 \mu \mathrm{M}$ roscovitine in a basal buffer containing $100 \mu \mathrm{M}$ ATP instead of $100 \mu \mathrm{M}\left[\gamma_{-}{ }^{32} \mathrm{P}\right]$-ATP for $1 \mathrm{hr}$ at $32^{\circ} \mathrm{C}$. After this, the complex was incubated with glutathione-Agarose (Sigma) for $1 \mathrm{hr}$ at $4^{\circ} \mathrm{C}$. The glutathione-Agarose was replaced in a $10 \mathrm{ml}$ column, and the column was washed with washing buffer containing Tris- $\mathrm{HCl}, \mathrm{pH} 7.4,150 \mathrm{~mm} \mathrm{NaCl}$, and $0.4 \%$ Triton X-100 and was then washed with PBS once. Solubilized synaptosome protein $(300 \mu \mathrm{g})$ was 
loaded on the column. The column was washed with washing buffer containing Tris- $\mathrm{HCl}, \mathrm{pH} 7.4,150 \mathrm{mM} \mathrm{NaCl}, 20 \mu \mathrm{M} \mathrm{CaCl}_{2}$, and $0.1 \%$ Triton X-100 three times. After the protein complexes were collected with glutathione-Agarose, the complex was denatured with boiled SDSPAGE buffer and centrifuged. Then, the supernatants were used for Western blot analysis using anti-SNAP-25 antibody (Transduction Laboratories, Lexington, KY), anti-synaptotagmin I antibody (Santa Cruz Biotechnology), and anti-syntaxin 1 antibody (Calbiochem, San Diego, CA), respectively.

\section{RESULTS}

\section{The effect of Cdk5 inhibitors, roscovitine and} olomoucine, on EPSP slopes

Roscovitine is a potent, membrane-permeable, specific Cdk5 inhibitor in neurons (Meijer et al., 1997). To demonstrate whether $\mathrm{Cdk} 5$ regulates neurotransmission, hippocampal slices were incubated with $10 \mu \mathrm{M}$ roscovitine, and the EPSP slopes were measured. After the roscovitine application, the EPSP slope gradually increased (Fig. 1A). The EPSP slope reached a maximum (178 \pm $10.2 \%$ of baseline) at $40 \mathrm{~min}$ after the roscovitine application. After washing out the roscovitine, the enhanced EPSP slope gradually decreased. The EPSP slope returned to the baseline 50 min after the washout, suggesting that the effect of roscovitine on the EPSP slope was reversible. To demonstrate the dosedependent effect of roscovitine on the EPSP slopes, hippocampal slices were incubated with each concentration of roscovitine until the maximal EPSP was recorded. Roscovitine dose-dependently increased the EPSP slope, and the effect was saturated at $10 \mu \mathrm{M}$ (Fig. 1B). Olomoucine is also a potent inhibitor of Cdks (Vesely et al., 1994). However, the $\mathrm{IC}_{50}$ against $\mathrm{Cdk} 5 / \mathrm{p} 35$ is $>10$-fold higher than that of roscovitine (Meijer et al., 1997). Olomoucine at $<10 \mu \mathrm{M}$ had no effect on the EPSP slope (Fig. 1C). However, application of $100 \mu \mathrm{M}$ olomoucine significantly increased the EPSP slope (maximum $130 \pm 7.8 \%$ of baseline). The effect of olomoucine was also reversible (data not shown). These data suggest that $\mathrm{Cdk} 5$ inhibitors enhance neurotransmission.

\section{Roscovitine affects paired-pulse facilitation}

To clarify that the effect of Cdk5 inhibitors on the neurotransmission is in presynapse or in postsynapse, we examined the paired-pulse facilitation (PPF). PPF is a more transient form of presynaptic plasticity in which the second of two closely spaced stimuli elicits enhanced transmitter release, because of residual calcium in the presynaptic terminal after the first stimulus (Zucker, 1989). The PPF was markedly reduced in the roscovitine-perfused hippocampal slices compared with the control slices when paired-pulse stimuli of 50-100 msec intervals were applied (Fig. 2). These data suggest that roscovitine acts in the presynaptic terminal and regulates neurotransmission.

\section{The expressions of Cdk5 and p35 in purified synaptosomes}

To demonstrate whether both Cdk5 and p35 exist in the presynaptic terminal, we tested the expressions of C dk5 and p35 in the purified synaptosomes (Fig. 3). Subcellular fractionation showed that $\mathrm{Cdk} 5$ was widely expressed, with no obvious concentration in one fraction. In contrast, p35 was enriched in isolated nerve terminals (P3 and LP2 fractions) to approximately the same extent as an insoluble presynapse marker, synaptophysin. In purified synaptosomes, Cdk5 existed in both the soluble (LS2) and insoluble (LP2) fractions. In contrast, p35 was expressed only in LP2 but not seen in LS2, as with Amphiphysin, which tightly associated with the synaptic vesicles (Fig. 3). These results suggest that $\mathrm{Cdk} 5$ and its activator, $\mathrm{p} 35$, are expressed in the presynaptic

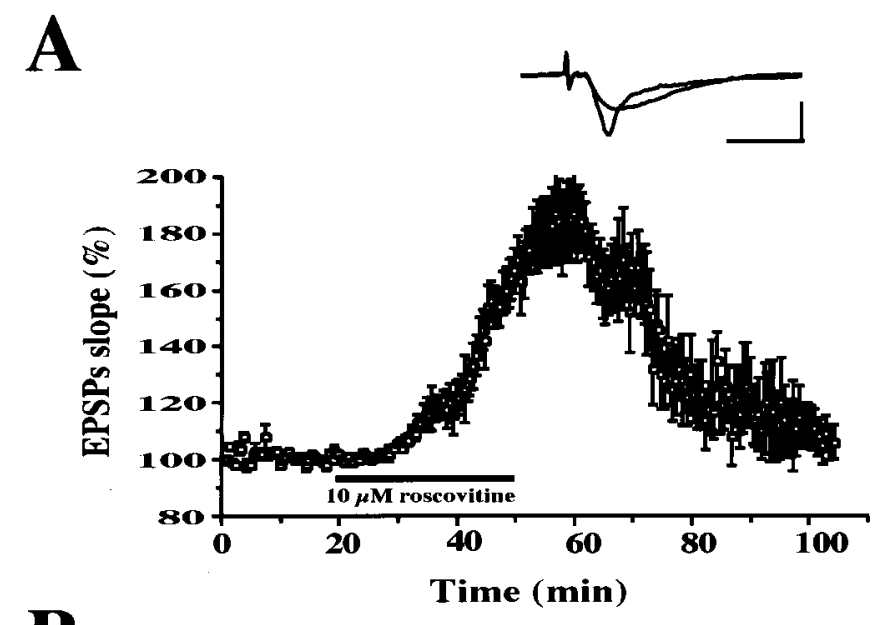

B


Figure 1. $\mathrm{Cdk} 5$ inhibitors enhanced the field EPSP slope. $A$, Hippocampal slices were perfused with $10 \mu \mathrm{M}$ roscovitine for $35 \mathrm{~min}$, and then the slices were washed out by perfusion with ACSF. Inset, Representative field EPSPs before and $40 \mathrm{~min}$ after the perfusion of roscovitine are shown. Calibration: $20 \mathrm{msec}, 2 \mathrm{mV}$. B, Dose-dependent effect of roscovitine on maximum EPSPs. To record the maximum EPSP, each concentration of roscovitine was applied until the maximum and stable EPSP was recorded. Each column is the mean \pm SEM values of five independent slices. The significance of differences was calculated by the Scheffe's test after ANOVA. ${ }^{*} p<0.05$ and ${ }^{* *} p<0.01$ compared with the control slices $(0 \mu \mathrm{M}) . C$, Dose-dependent effect of olomoucine on the maximum EPSPs. The conditions of drug application were the same as those of roscovitine. Values were significantly different from the control slices $(0 \mu \mathrm{M}) ;{ }^{*} p<$ 0.05 . 


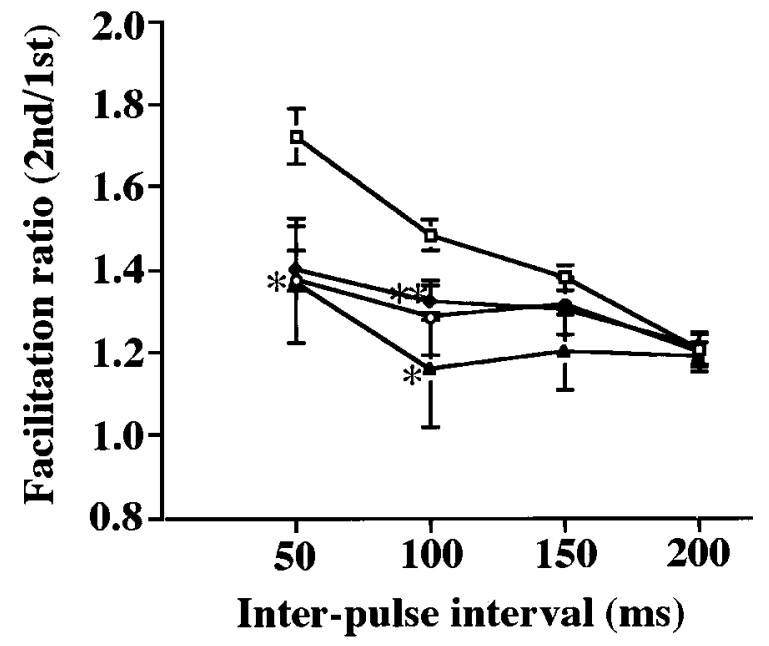

Figure 2. Roscovitine reduced PPF in hippocampal slices. The hippocampal slices were incubated with each concentration of roscovitine $(\square, 0 \mu \mathrm{M} ; \diamond, 1 \mu \mathrm{M} ; \bigcirc, 5 \mu \mathrm{M} ; \boldsymbol{\Delta}, 10 \mu \mathrm{M})$ for $50 \mathrm{~min}$, after which PPF was induced by two pulses of stimulation separated by intervals of $50,100,150$, and $200 \mathrm{msec}$. Data show the ratios of the second EPSP slopes and the first EPSP slopes. The significance of difference was calculated by the Scheffe's test after ANOVA. ${ }^{*} p<0.05$ and ${ }^{*} p p<0.01$ compared with the control slices $(0 \mu \mathrm{M})$.

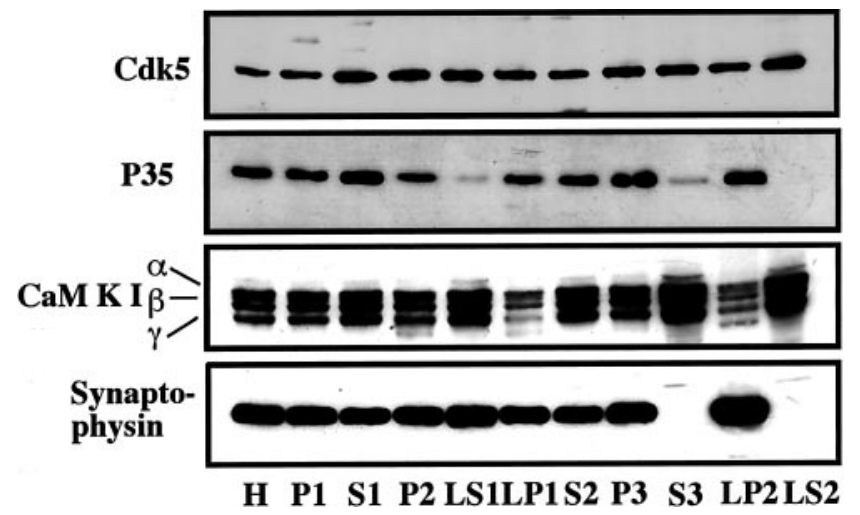

Figure 3. Both Cdk5 and p35 were enriched in purified synaptosomes. Western blot analyses for Cdk5, p35, calmodulin kinase I (CaM KI, soluble presynapse fraction marker), and synaptophysin (insoluble presynapse fraction marker) of the rat brain subcellular fractions are shown. Each fraction is shown in Materials and Methods. H, Total homogenate; $P 2$, crude synaptosomes; $L P 2$, membrane fraction of the purified synaptosomes; $L S 2$, cytosolic fraction of the purified synaptosomes.

terminal and that p35 may be tightly associated with membranes or vesicles.

\section{Roscovitine upregulates glutamate release from synaptosomes}

The present data show that Cdk5 inhibitors block the Cdk5 activity in the presynaptic terminal, resulting in the induction of neurotransmission. These data lead to a hypothesis that $\mathrm{Cdk} 5$ regulates neurotransmitter release. We demonstrated the effect of roscovitine on glutamate release from the synaptosomes (Fig. 4). Preincubation of the synaptosomes with roscovitine $(5$ or $10 \mu \mathrm{M})$ resulted in a significant increase in the 4AP-evoked glutamate release compared with the control (5 $\mu \mathrm{M}$ roscovitine, $7.2 \pm 0.4 \mathrm{nmol} / \mathrm{mg}$ per $4 \mathrm{~min} ; 10 \mu \mathrm{M}$ roscovitine, $9.0 \pm 1.7 \mathrm{nmol} / \mathrm{mg}$ per $4 \mathrm{~min}$; control, $5.5 \pm 1.1 \mathrm{nmol} / \mathrm{mg}$

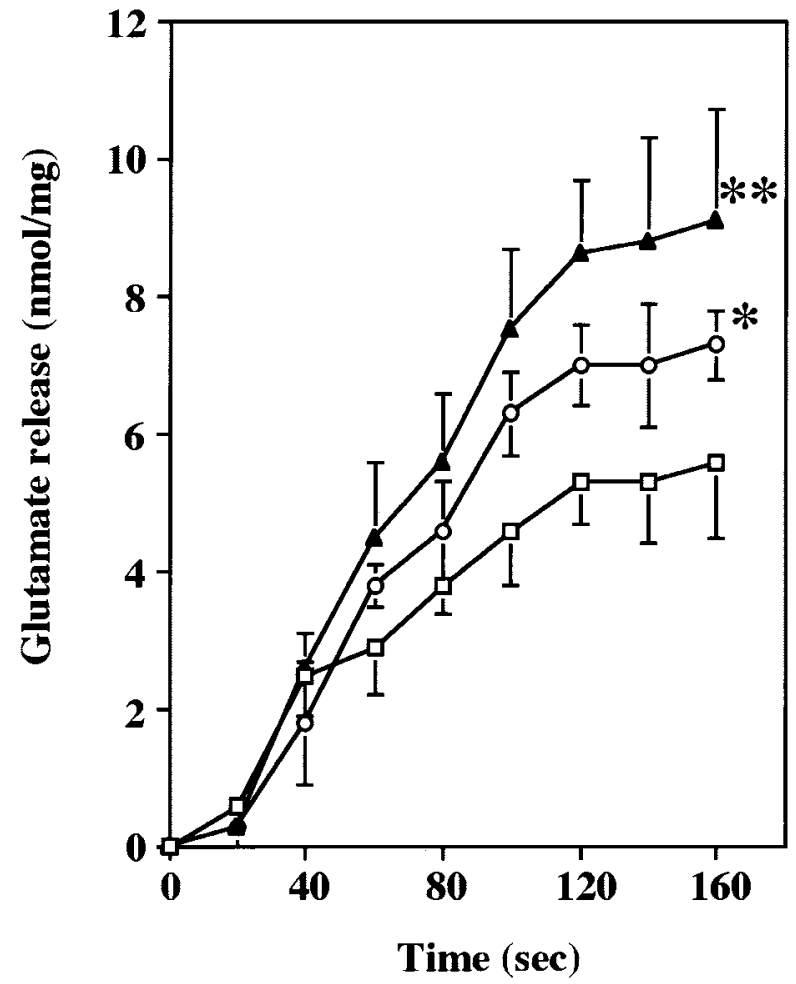

Figure 4. The effect of roscovitine on $\mathrm{Ca}^{2+}$-dependent glutamate release from synaptosomes prepared from rat brains in response to membrane depolarization with $1 \mathrm{~mm} 4-\mathrm{AP}(n=5)$. Data represent the mean \pm SEM values of five independent experiments. The synaptosomes were incubated with each concentration of roscovitine $(\square, 0 \mu \mathrm{M} ; \bigcirc, 5 \mu \mathrm{M} ; \boldsymbol{\Delta}, 10$ $\mu \mathrm{M})$ for $30 \mathrm{~min}$, and then 4 -AP was added at $0 \mathrm{sec}$. Values significantly different from the control synaptosomes ( $0 \mu \mathrm{M}$ roscovitine) are indicated $\left({ }^{*} p<0.05 ; * * p<0.01 ;\right.$ Scheffe's test $)$.

per $4 \mathrm{~min}$ ). This result indicates that $\mathrm{Cdk} 5$ inhibits neurotransmitter release.

\section{Roscovitine enhances the activation of $P / Q$-type voltage-dependent calcium channel}

Bibb et al. (1999) have reported that the application of roscovitine enhanced whole-cell $\mathrm{Ca}^{2+}$ current in striatum neurons. These data and our results lead to a hypothesis that $\mathrm{Cdk} 5$ may enhance the activity of presynaptic VDCC, resulting in increased neurotransmitter release. In the cultured hippocampal neurons, $\mathrm{N}$ - and P/Q-type VDCCs predominantly mediate excitatory synaptic transmission (Wheeler et al., 1996; Reid et al., 1997). Coapplication of $\omega$-CgTx GVIA and $\omega$-Aga IVA, which are specific inhibitors of N-type and P/Q-type VDCCs, respectively, completely blocked the EPSP slope $(>98 \%)$ in the hippocampal slices, suggesting that $\mathrm{N}$ - and $\mathrm{P} / \mathrm{Q}$-type VDCCs specifically regulated neurotransmitter release in the hippocampal slices (Fig. $5 A$ ). To investigate whether roscovitine affects the activity of theses VDCCs, its effect on each channel-dependent EPSP slope was examined. An application of $\omega$-CgTx GVIA reduced the EPSP slope by $44 \pm 3.6 \%$. After the EPSP slopes became stable, $5 \mu \mathrm{M}$ roscovitine was applied. An application of roscovitine gradually induced the EPSP slope by $31.5 \pm 4.9 \%$ (Fig. $5 B$ ). In contrast, $\omega$-Aga IVA, a specific blocker of P/Q-type VDCC, significantly reduced the EPSP slope $(21 \pm 8.1 \%) 25$ min after the application), and an application of roscovitine had no effect on the $\omega$-Aga IVA-reduced EPSP slope (Fig. 5C). These data suggest that roscovitine specifically enhances $\mathrm{P} / \mathrm{Q}$-type VDCC activity. 


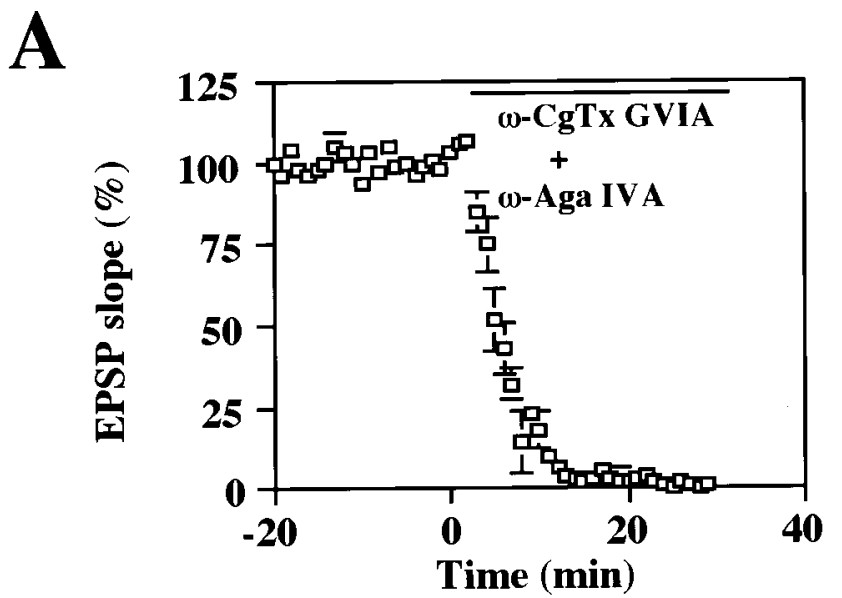

B
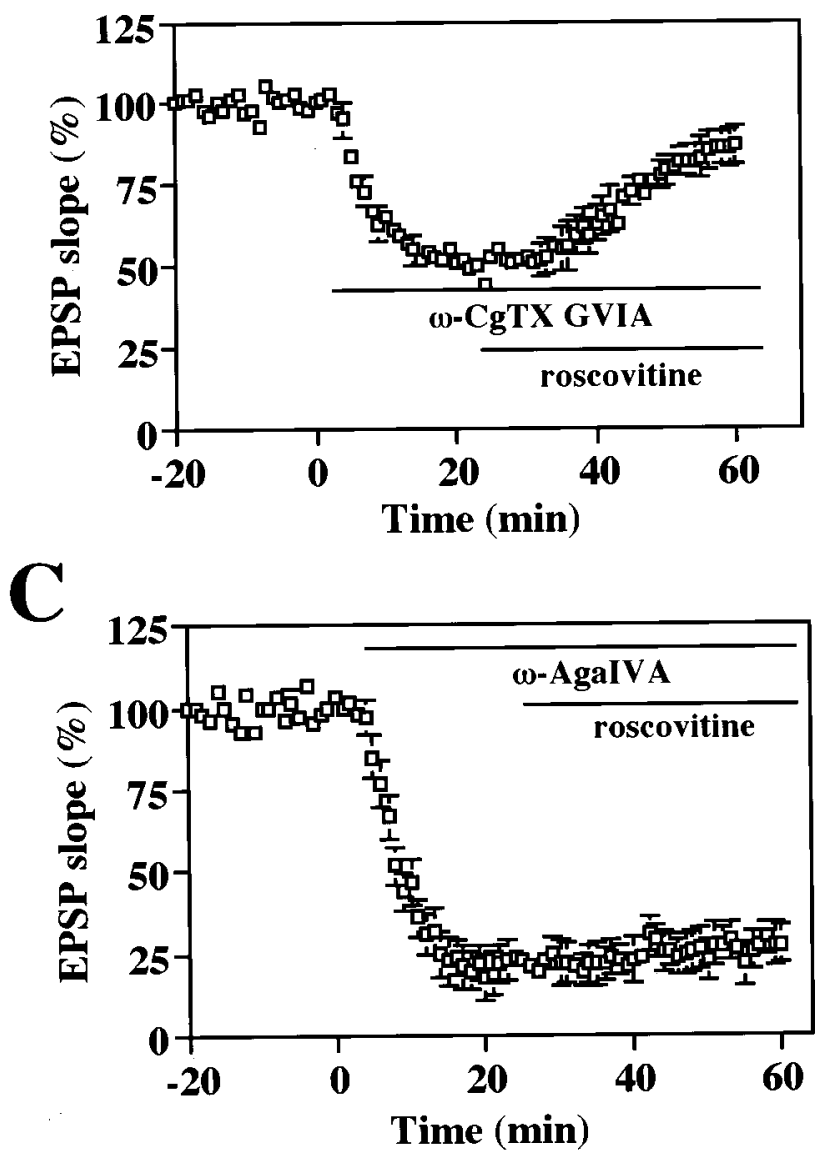

Figure 5. The effect of roscovitine on the EPSP slope in the presence of $\omega$-CgTx GVIA and $\omega$-Aga IVA. Hippocampal slices were incubated with $1 \mu \mathrm{M} \omega$-CgTx GVIA and $0.5 \mu \mathrm{M} \omega$-Aga IVA $(A), 1 \mu \mathrm{M} \omega$-CgTx GVIA $(B)$, or $0.5 \mu \mathrm{M} \omega$-Aga IVA $(C)$. Then, $10 \mu \mathrm{M}$ roscovitine was applied after recording stable EPSP slopes. The drugs were perfused continuously until the end of the experiment.

We further demonstrated the effect of roscovitine on calcium entry from the $\mathrm{P} / \mathrm{Q}$-type $\mathrm{VDCC}$ channel using $\mathrm{Ca}^{2+}$ imaging. To record the specific $\mathrm{Ca}^{2+}$ influx from the $\mathrm{P} / \mathrm{Q}$-type VDCC channel, the hippocampal neurons were incubated with $25 \mu \mathrm{M} \mathrm{AP5,}$ $0.5 \mu \mathrm{M} \omega$-CgTx GVIA, and $10 \mu \mathrm{M}$ Nifedipine, which were specific inhibitors of other types of VDCCs and NMDA receptor. The cells were then stimulated by high $\mathrm{K}^{+}$in the presence or absence
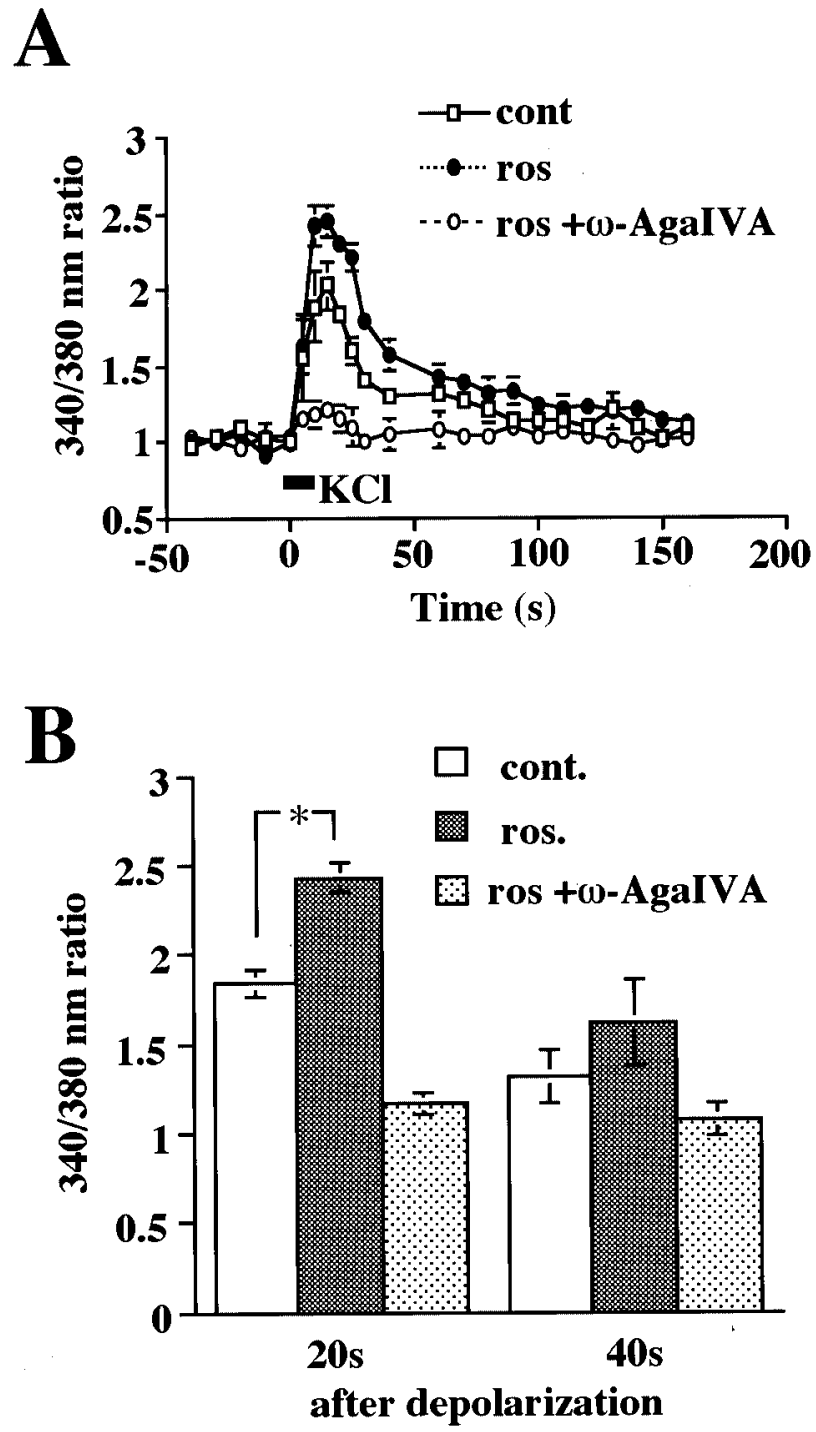

Figure 6. Roscovitine enhanced $\mathrm{Ca}^{2+}$ influx from P/Q-type VDCCs. $A$, Primary cultured hippocampal neurons were incubated with $\omega$-CgTx GVIA, Nifedipine, and AP-5 to measure the $\mathrm{Ca}^{2+}$ influx specific from P/Q-type VDCCs for $30 \mathrm{~min}$. Roscovitine was also applied $30 \mathrm{~min}$ before depolarization. The cells were exposed with $50 \mathrm{~mm} \mathrm{KCl}$ for $10 \mathrm{sec}$, and fura-2 AM fluorescence was recorded using a video image analysis system (AquaCosmos, Hamamatsu Photonics), with excitation alternatively at 340 and $380 \mathrm{~nm}$, and emission at $510 \mathrm{~nm}$ ( $\square$, control; $\bullet, 5 \mu \mathrm{M}$ roscovitine; $\bigcirc$, roscovitine and $\omega$-Aga IVA). $B$, Comparison of $\mathrm{Ca}^{2+}$ influx from P/Q-type VDCCs at 20 and $40 \mathrm{sec}$ after depolarization. Data from 20-30 individual cells were collected per experiment, and ensemble averages were calculated for multiple experiments $(n>30)$. Data were analyzed using ANOVA followed by planned comparisons of the multiple conditions. ${ }^{*} p<0.01$.

of roscovitine. In the control neurons, the intracellular $\mathrm{Ca}^{2+}$ concentration increased after the high $\mathrm{K}^{+}$stimulation (Fig. 6A). The increased $\mathrm{Ca}^{2+}$ influx gradually decreased after washing out, and $\mathrm{Ca}^{2+}$ entry was not recorded 3 min after the high $\mathrm{K}^{+}$ stimulation. An application of roscovitine significantly enhanced the maximal $\mathrm{Ca}^{2+}$ influx from the $\mathrm{P} / \mathrm{Q}$-type $\mathrm{VDCC}$ channel compared with that in the control neurons (Fig. 6A,B). The enhanced $\mathrm{Ca}^{2+}$ influx was rapidly decreased after washing out $\mathrm{KCl}$ (Fig. 6A). A significant $\mathrm{Ca}^{2+}$ influx was observed $20 \mathrm{sec}$ after the high $\mathrm{K}^{+}$stimulation but not observed $40 \mathrm{sec}$ after the stimulation (Fig. 6B). Moreover, $\omega$-Aga IVA, a specific blocker of the 
P/Q-type VDCC blocker, significantly reduced the roscovitineinduced $\mathrm{Ca}^{2+}$ influx from P/Q-type VDCC. These results directly showed that the inhibition of $\mathrm{Cdk} 5$ activity enhanced the $\mathrm{Ca}^{2+}$ influx from the P/Q-type VDCC channel.

Cdk5/p35-dependent phosphorylation of $\mathrm{L}_{\text {lI-III }}$ of rbA isoform of the $\alpha_{1 \mathrm{~A}}$ subunit of $\mathrm{P} / \mathrm{Q}$-type $\mathrm{Ca}^{2+}$ channels and the regulation of the interaction with SNAP-25 and synaptotagmin

What is the mechanism of the induction of the activity of $\mathrm{P} / \mathrm{Q}-$ type VDCCs by $\mathrm{Cdk}$ 5-specific inhibitors? $\mathrm{P} / \mathrm{Q}$-type $\mathrm{Ca}^{2+}$ channels contain pore-forming $\alpha_{1 \mathrm{~A}}$ subunits in association with $\beta$ and $\alpha_{2 \delta}$ subunits (Catterall, 1998). The distinct $\alpha_{1 \mathrm{~A}}$ isoforms cloned from rat brain (rbA) and rabbit brain (BI) have synprint sites with different specificities for interactions with plasma-membrane SNARE proteins, such as SNAP-25, synaptotagmin, and syntaxin (Catterall, 1998; Seagar and Takahashi, 1998). Disrupting interactions between these SNARE proteins and $\mathrm{Ca}^{2+}$ channels inhibits neurotransmission, demonstrating that such interaction is required for efficient neurotransmitter release (Catterall, 1998). Phosphorylation of the synaptic protein interaction site on N-type calcium channels inhibits the interaction with SNAP-25 and syntaxin, resulting in the inhibition of channel activity (Yokoyama et al., 1997). These results lead to a hypothesis that Cdk5 directly phosphorylates the $\alpha_{1 \mathrm{~A}}$ isoform of P/Q-type VDCCs, resulting in the inhibition of the interaction with SNARE proteins.

To clarify the hypothesis, we demonstrated whether Cdk5/p25 phosphorylated $\mathrm{L}_{\mathrm{II}-\mathrm{III}}$ (synprint site) of the rbA isoform of the $\alpha_{1 \mathrm{~A}}$ subunit (Fig. 7). Cdk5/p25 phosphorylated synprint polypeptides (Fig. 7A). Stoichiometric analysis revealed that the synprint $\alpha_{1 \mathrm{~A}}$ was a good substrate for $\mathrm{Cdk} 5 / \mathrm{p} 25$, with a maximal stoichiometry of $1.5 \mathrm{~mol} / \mathrm{mol}$. Although the correlation of stoichiometry measurements with the precise number of phosphorylated residues is not possible from this analysis, there are clearly multiple good substrate sites for Cdk5 in the synprint peptide. The rbA isoform of $\alpha_{1 \mathrm{~A}}$ binds SNAP-25 in a calcium-independent manner. In contrast, the binding of the isoform with synaptotagmin is calcium dependent, with maximum binding at 10-30 $\mu \mathrm{M}$ (Catterall, 1998). Therefore, we incubated phospho- and dephosphoGST- $\mathrm{L}_{\text {II-III }}$ proteins with synaptosomes in HEPES buffer with 20 $\mu \mathrm{M}$ calcium. Phosphorylation of the synprint peptides blocked the binding of the peptides with both SNAP-25 and synaptotagmin I (Fig. 7C). These inhibitions of the phosphorylation-dependent binding with SNAP-25 and synaptotagmin I were blocked by an application of roscovitine (Fig. 7C). On the other hand, syntaxin I did not bind to the synprint peptides of P/Q-type VDCCs regardless of the phosphorylation and dephosphorylation (data not shown). These data suggest that $\mathrm{Cdk} 5 / \mathrm{p} 25$ phosphorylates $\mathrm{L}_{\text {II-III }}$ of the rbA isoform of the $\alpha_{1 \mathrm{~A}}$ subunit of P/Q-type VDCCs, resulting in the inhibition of the association with SNAP-25 and synaptotagmin, and roscovitine blocked the Cdk5-dependent inhibition of these associations. In contrast, $\mathrm{Cdk} 5 / \mathrm{p} 25 \mathrm{did}$ not phosphorylate $\mathrm{L}_{\mathrm{II}-\mathrm{III}}(718-963)$ of the $\alpha_{1 \mathrm{~B}}$ subunit of rat N-type calcium channel, which is phosphorylated by protein kinase $\mathrm{A}$ and CaM KII, and regulated the interaction with SNARE proteins (data not shown).

\section{DISCUSSION}

These results provide four important findings as follows. First, Cdk5 inhibitors enhanced neurotransmission in hippocampal slices. Second, the regulation of neurotransmission by $\mathrm{Cdk} 5$ is performed in the presynaptic terminal. Third, Cdk5 inhibitors
A

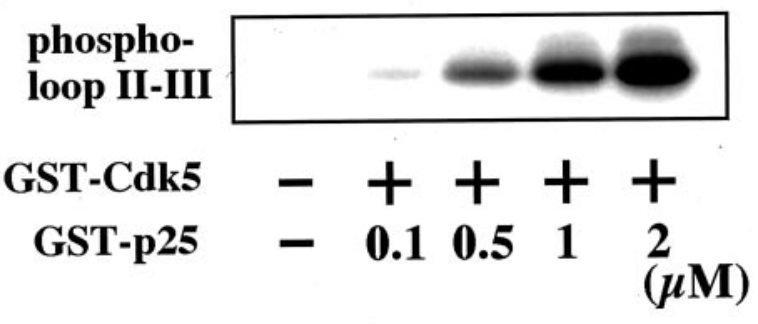

B

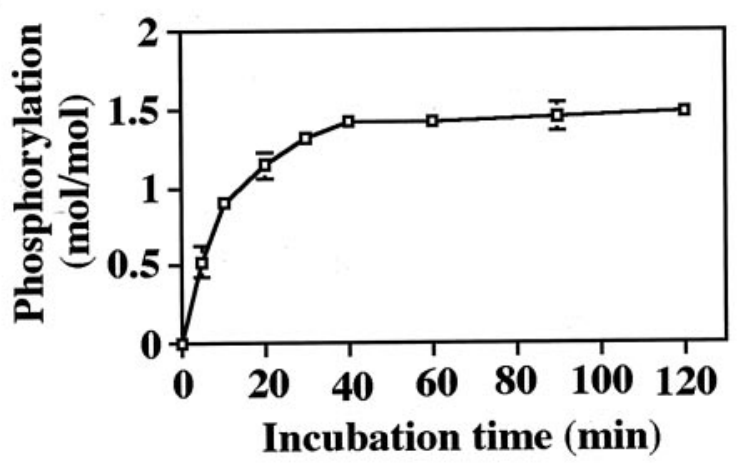

C

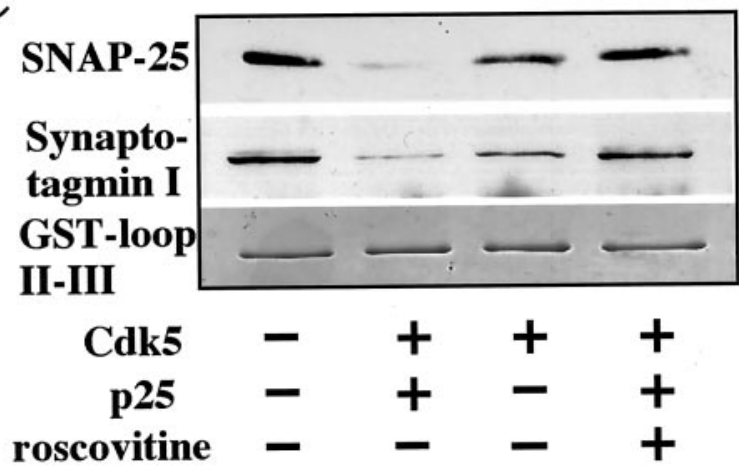

Figure 7. $\mathrm{Cdk} 5 / \mathrm{p} 35$-dependent phosphorylation of $\mathrm{L}_{\mathrm{II}-\mathrm{III}}$ of $\mathrm{rbA}$ isoform of the $\alpha_{1 \mathrm{~A}}$ subunit of P/Q-type $\mathrm{Ca}^{2+}$ channels and the regulation of the interaction with SNARE proteins. $A$, Purified GST- $\mathrm{L}_{\text {II-III }}$ peptides were incubated with GST-Cdk5 or each concentration of GST-p25 at $32^{\circ} \mathrm{C}$ for 30 min. GST- $\mathrm{L}_{\text {II-III }}$ peptides were phosphorylated by GST-Cdk5 correlating with GST-p25 concentration. $B$, Stoichiometry of phosphorylation for GST- $\mathrm{L}_{\text {II-III }}$. Polypeptides of GST- $\mathrm{L}_{\text {II-III }}$ were phosphorylated with GST-Cdk5/p25 for the indicated time periods. $C$, Phosphorylation of GST- $\mathrm{L}_{\text {II-III }}$ inhibited the interaction with SNAP-25 and synaptotagmin. Polypeptides of GST- $\mathrm{L}_{\text {II-III }}$ were incubated with purified $\mathrm{Cdk} 5 / \mathrm{p} 25$ or 5 $\mu \mathrm{M}$ roscovitine. Then the complex was incubated with glutathione-Agarose. The glutathione-Agarose was replaced in a $10 \mathrm{ml}$ column. After the column was washed, the solubilized synaptosome protein $(300 \mu \mathrm{g})$ in HEPES buffer with $20 \mu \mathrm{M} \mathrm{CaCl}_{2}$ was loaded on the column, and the column was washed. After the protein complexes were collected with glutathione-Agarose, the complex was denatured with boiled SDS-PAGE buffer. The supernatants were then used for Western blot analysis using anti-SNAP-25 antibody, anti-synaptotagmin I antibody, and anti-syntaxin I antibody, respectively. Top panel, Result of Western blot analysis with anti-SNAP-25 antibody. Middle panel, Result of Western blot analysis with anti-synaptotagmin I antibody. Bottom panel, After the complex was collected with glutathione-Agarose, the proteins were separated in SDSPAGE gel. Then, the gel was stained by Coomassie blue, and the polypeptides of GST- $\mathrm{L}_{\mathrm{II}-\mathrm{III}}$ were visualized. 
enhanced $\mathrm{Ca}^{2+}$ entry from P/Q-type VDCCs. Fourth, Cdk5/p25 phosphorylated the intracellular loop connecting domains II and III corresponding to amino acid residues 724 and 981 of the rbA isoform of the $\alpha_{1 \mathrm{~A}}$ subunit of $\mathrm{P} / \mathrm{Q}$-type $\mathrm{Ca}^{2+}$ channels, and the phosphorylation inhibited the interaction with SNAP-25 and synaptotagmin.

\section{Cdk5 is a multifunctional kinase in the developing, adult, and aging brain}

Cdk5/p35 plays an important role in neuronal migration and differentiation in immature neurons (Nikolic et al., 1996; Chae et al., 1997). The complex of Cdk5/p35 is colocalized with Pak1 in the axonal growth cone, and the kinase downregulates Pak1 kinase activity (Nikolic et al., 1998), resulting in neurite outgrowth. Moreover, it has recently been reported that $\mathrm{Cdk} 5$ phosphorylated NUDEL, a novel LIS-1-interacting protein in the growth cone (Niethammer et al., 2000). The inhibition of Cdk5 activity with roscovitine alters NUDEL localization and its association with the dynein complex, resulting in the alteration of neuronal migration (Niethammer et al., 2000). These data suggest that in the immature neuron, the Cdk5/p35 complex localizes in the growth cones and regulates neuronal migration, differentiation, and synaptogenesis.

In the mature neuron, in contrast, $\mathrm{Cdk} 5$ is expressed in the presynaptic terminals (Matsushita et al., 1996) (present results), and the enzyme phosphorylates presynaptic proteins such as Munc18 (Shuang et al., 1998), Synapsin I (Jovanovic et al., 1996), and Amphiphysin I (Rosales et al., 2000). These data suggest that Cdk5 changes localization from the growth cone to the axon (presynaptic terminal) and regulates neurotransmitter release in the adult brain.

Moreover, recent studies have shown that in Alzheimer's brain, p35 is truncated to p25, and the complex of Cdk5 and p25 leads to mislocalization of the kinase to the soma, resulting in neuronal degeneration (Patrick et al., 1999; Lee et al., 2000). These studies suggest that $\mathrm{Cdk} 5$ has multiple and different functions in the developing, adult, and aging neuron and that the change in localization of $\mathrm{Cdk} 5$ is an important mechanism underlying the different functions of Cdk5.

\section{The mechanism of Cdk5-dependent regulation of P/Q-type VDCC activity}

Our data first showed that $\mathrm{Cdk} 5$ inhibitors enhanced neurotransmitter release via enhancement of the activity of $\mathrm{P} / \mathrm{Q}$-type VDCCs. Moreover, we showed that Cdk5 phosphorylated the $\mathrm{L}_{\text {II-III }}$ of $\mathrm{P} / \mathrm{Q}$-type calcium channels, and the phosphorylation inhibited the interaction with SNAP-25 and synaptotagmin.

The synprint site on the N-type VDCC $\alpha_{1 \mathrm{~B}}$ subunit is phosphorylated, and the phosphorylation inhibits interaction with SNARE proteins such as syntaxin and SNAP-25 (Yokoyama et al., 1997). We demonstrated that Cdk5 phosphorylated the synprint site on N-type VDCCs; however, Cdk5 did not phosphorylate the $\mathrm{L}_{\mathrm{II}-\mathrm{III}}$ peptides of the VDCCs. Immunocytochemical and pharmacological experiments provide evidence that $\mathrm{N}$-type VDCCs regulate neurotransmitter release at both peripheral and central synapses (Westenbroek et al., 1992). In contrast, P/Q-type VDCCs are present in high density at central synapses (Westenbroek et al., 1995), and transmitter release primarily requires $\mathrm{P} / \mathrm{Q}$-type channels, with $\mathrm{N}$-type channels playing a secondary role (Catterall, 1998). The present results showed that the inhibition of the EPSP slope by $\omega$-Aga IVA, a specific blocker of P/Q-type VDCCs, is much greater than that by $\omega$-CgTx GVIA, a specific blocker of N-type VDCCs in the hippocampus. These results suggest that $\mathrm{Ca}^{2+}$ entry from P/Q-type VDCCs might be more important in regulating neurotransmitter release than that from N-type VDCCs in the hippocampus.

The synaptic vesicle proteins synaptotagmin and synaptobrevin/vesicle-associated membrane protein bind to the synaptic plasma membrane SNARE proteins syntaxin and SNAP-25 to form a core complex implicated in synaptic vesicle docking and membrane fusion (Hanson et al., 1997). This core complex associates with N-type and P/Q-type VDCCs via $\mathrm{L}_{\text {II-III }}$ (Catterall, 1998). Disruption of interactions between SNARE proteins and these $\mathrm{Ca}^{2+}$ channels inhibits neurotransmission, demonstrating that such interaction is required for efficient neurotransmitter release (Catterall, 1998). These previous data agree with our present results that $\mathrm{Cdk} 5$ phosphorylated $\mathrm{L}_{\mathrm{II}-\mathrm{III}}$ of $\mathrm{P} / \mathrm{Q}$-type VDCCs, resulting in the disruption of the interaction with SNAP-25 and synaptotagmin I. These data suggest that Cdk5 might downregulate the activity of the rbA isoform of $\mathrm{P} / \mathrm{Q}$-type VDCCs through phosphorylation of $\mathrm{L}_{\text {II-III }}$ of the calcium channel and inhibition of the interaction with SNARE proteins. The present results showed that syntaxin I did not bind to $\mathrm{L}_{\mathrm{II}-\mathrm{III}}$ of the $\mathrm{rbA}$ isoform of $\mathrm{P} / \mathrm{Q}$-type VDCCs regardless of the phosphorylation and dephosphorylation. These data agree with the previous results that the rbA isoform of P/Q-type VDCCs binds SNAP-25 but not syntaxin (Rettig et al., 1996; Zhong et al., 1999).

Voltage-dependent calcium channels, which are involved in neurotransmitter release, are strictly regulated by the activity of the specific SNARE proteins (Sheng et al., 1996; Catterall, 1998). The interaction of $\mathrm{N}$-type $\mathrm{Ca}^{2+}$ channels with syntaxin and SNAP-25 is $\mathrm{Ca}^{2+}$ dependent and regulated by protein phosphorylation (Yokoyama et al., 1997). The interaction of the calcium channels with SNARE proteins may be regulated by phosphorylation and dephosphorylation. Cdk5 may be one of the most important kinases that regulate neurotransmitter release.

In conclusion, we have shown that both $\mathrm{Cdk} 5$ and p35 are abundant in the presynaptic terminals and that $\mathrm{Cdk} 5$ inhibitors enhance neurotransmitter release. The induction of the neurotransmitter release by $\mathrm{Cdk} 5$ inhibitors is caused by the regulation of $\mathrm{P} / \mathrm{Q}$-type voltage-dependent $\mathrm{Ca}^{2+}$ channel activity. Our results indicate that $\mathrm{Cdk} 5$ regulates the neurotransmitter release in the presynaptic terminals of the adult brain.

\section{REFERENCES}

Bibb JA, Snyder GL, Nishi A, Yan Z, Meijer L, Fienberg AA, Tsai LH, Kwon YT, Girault JA, Czernik AJ, Huganir RL, Hemmings Jr HC, Nairn AC, Greengard P (1999) Phosphorylation of DARPP-32 by $\mathrm{Cdk} 5$ modulates dopamine signalling in neurons. Nature 402:669-671. Catterall WA (1998) Structure and function of neuronal $\mathrm{Ca}^{2+}$ channels and their role in neurotransmitter release. Cell Calcium 24:307-323.

Chae T, Kwon YT, Bronson R, Dikkes P, Li E, Tsai LH (1997) Mice lacking p35, a neuronal specific activator of $\mathrm{Cdk} 5$, display cortical lamination defects, seizures, and adult lethality. Neuron 18:29-42.

Dunlap K, Luebke JI, Turner TJ (1995) Exocytotic $\mathrm{Ca}^{2+}$ channels in mammalian central neurons. Trends Neurosci 18:89-98.

Floyd SR, Porro EB, Slepnev VI, Ochoa GC, Tsai LH, De Camilli P (2001) Amphiphysin binds the cdk5 regulatory subunit p35 and is phosphorylated by cdk5 and cdc2. J Biol Chem 276:8104-8110.

Hanson PI, Heuser JE, Jahn R (1997) Neurotransmitter release: four years of SNARE complexes. Curr Opin Neurobiol 7:310-315.

Huttner WB, Schiebler W, Greengard P, De Camilli P (1983) Synapsin I (protein I), a nerve terminal-specific phosphoprotein. III. Its association with synaptic vesicles studied in a highly purified synaptic vesicle preparation. J Cell Biol 96:1374-1388.

Jovanovic JN, Benfenati F, Siow YL, Sihra TS, Sanghera JS, Pelech SL, Greengard P, Czernik AJ (1996) Neurotrophins stimulate phosphorylation of synapsin I by MAP kinase and regulate synapsin I-actin interactions. Proc Natl Acad Sci USA 93:3679-3683.

Kim DK, Catterall WA (1997) $\mathrm{Ca}^{2+}$-dependent and -independent interactions of the isoforms of the $\alpha_{1 \mathrm{~A}}$ subunit of brain $\mathrm{Ca}^{2+}$ channels 
with presynaptic SNARE proteins. Proc Natl Acad Sci USA 94:14782-14786

Lee K-Y, Rosales JL, Tang D, Wang JH (1996) Interaction of cyclindependent kinase $5(\mathrm{Cdk} 5)$ and neuronal $\mathrm{Cdk} 5$ activator in bovine brain. J Biol Chem 271:1538-1543.

Lee M-S, Kwon YT, Li M, Peng J, Friedlander RM, Tsai L-H (2000) Neurotoxicity induces cleavage of p35 to p25 by calpain. Nature 405:360-364.

Lew J, Wang JH (1995) Neuronal cdc2-like kinase. Trends Biochem Sci 20:33-37.

Lew J, Winkfein RJ, Huang QQ, Qi Z, Aebersold R, Hunt T, Wang JH (1994) Neuronal cdc2-like kinase is a complex of cyclin-dependent kinase 5 and a novel brain-specific regulatory subunit. Nature 371:423-426.

Lu Y-F, Tomizawa K, Moriwaki A, Hayashi Y, Tokuda M, Itano T, Hatase O, Matsui H (1996) Calcineurin inhibitors, F K506 and cyclosporin A, suppress the NMDA receptor-mediated potentials and LTP, but not depotentiation in the rat hippocampus. Brain Res 729:142-146.

Lu Y-F, Kandel ER, Hawkins RD (1999) Nitric oxide signaling contributes to late-phase LTP and CREB phosphorylation in the hippocampus. J Neurosci 19:10250-10261.

Matsubara M, Kusubata M, Ishiguro K, Uchida T, Titani K, Taniguchi H (1996) Site-specific phosphorylation of synapsin I by mitogen-activated protein kinase and $\mathrm{Cdk} 5$ and its effects on physiological functions. J Biol Chem 271:21108-21113.

Matsushita M, Tomizawa K, Lu YF, Moriwaki A, Tokuda M, Itano T, Wang JH, Osamu H, Matsui H (1996) Distinct cellular compartment of cyclin-dependent kinase 5 ( $\mathrm{Cdk} 5)$ and neuron-specific $\mathrm{Cdk} 5$ activator protein $\left(\mathrm{p} 35^{\mathrm{nck} 5 \mathrm{a}}\right)$ in the developing rat cerebellum. Brain Res 734:319-322.

Meijer L, Borgne A, Mulner O, Chong JP, Blow JJ, Inagaki N, Inagaki M, Delcros JG, Moulinoux JP (1997) Biochemical and cellular effects of roscovitine, a potent and selective inhibitor of the cyclin-dependent kinases cdc2, cdk2 and cdk5. Eur J Biochem 243:527-536.

Moriwaki A, Lu YF, Hayashi Y, Tomizawa K, Tokuda M, Itano T, Hatase O, Matsui H (1996) Immunosuppressant FK506 prevents mossy fiber sprouting induced by kindling stimulation. Neurosci Res 25:191-194.

Nikolic M, Dudek H, Kwon YT, Ramos YF, Tsai LH (1996) The cdk5/ p35 kinase is essential for neurite outgrowth during neuronal differentiation. Genes Dev 10:816-825.

Nikolic M, Chou MM, Lu W, Mayer BJ, Tsai LH (1998) The p35/Cdk5 kinase is a neuron-specific rac effector that inhibits Pak1 activity. Nature 395:194-198.

Niethammer M, Smith DS, Ayala R, Peng J, Ko J, Lee M-S, Morabito M, Tsai LH (2000) NUDEL is a novel C dk5 substrate that associates with LIS1 and cytoplasmic dynein. Neuron 28:367-711.

Patrick GN, Zukerberg L, Nikolic M, de la Monte S, Dikkes P, Tsai LH (1999) Conversion of p35 to p25 deregulates Cdk5 activity and promotes neurodegeneration. Nature 402:615-622.

Reid CA, Clements JD, Bekkers JM (1997) Nonuniform distribution of $\mathrm{Ca}^{2+}$ channel subtypes on presynaptic terminals of excitatory synapses in hippocampal cultures. J Neurosci 15:2738-2745.

Rettig J, Sheng ZH, Kim DK, Hodson CD, Snutch TP, Catterall WA (1996) Isoform-specific interaction of the alpha1A subunits of brain $\mathrm{Ca}^{2+}$ channels with the presynaptic proteins syntaxin and SNAP-25. Proc Natl Acad Sci USA 93:7363-7368.

Rosales JL, Nodwell MJ, Johnston RN, Lee KY (2000) Cdk5/p25 nck5a interaction with synaptic proteins in bovine brain. J Cell Biochem 78:151-159.
Seagar M, Takahashi M (1998) Interactions between presynaptic calcium channels and proteins implicated in synaptic vesicle trafficking and exocytosis. J Bioenerg Biomembr 30:347-356.

Sheng ZH, Rettig J, Takahashi M, Catterall WA (1996) Calciumdependent interaction of N-type calcium channels with the synaptic core complex. Nature 379:451-454.

Shuang R, Zhang L, Fletcher A, Groblewski GE, Pevsner J, Stuenkel EL (1998) Regulation of Munc-18/syntaxin 1A interaction by cyclindependent kinase 5 in nerve endings. J Biol Chem 273:4957-4966.

Stula T, Xiao-Xian H Cavazos J, Scott G (1988) Synaptic reorganization in the hippocampus induced by abnormal functional activity. Science 239:1147-1150.

Tang D, Yeung J, Li K-Y, Matsushita M, Tomizawa K, Matsui H, Hatase O, Wang JH (1995) An isoform of neuronal cyclin-dependent kinase 5 (Cdk5) activator. J Biol Chem 270:26897-26903.

Tomizawa K, Matsui H, Matsushita M, Lew J, Tokuda M, Itano T, Konishi R, Wang JH, Hatase O (1996) Localization and developmental changes in the neuron-specific cyclin-dependent kinase 5 activator $\left(\mathrm{p} 35^{\text {nck5a }}\right)$ in the rat brain. Neuroscience 74:519-529.

Tomizawa K, Cai X-H, Moriwaki A, Matsushita M, Matsui H (2000) Involvement of cyclin-dependent kinase $5 / \mathrm{p} 35^{\text {nck5a }}$ in the synaptic reorganization of the rat hippocampus during kindling progression. Jpn J Physiol 50:525-532.

Tsai LH, Takahashi T, Caviness Jr V, Harlow E (1993) Activity and expression pattern of cyclin-dependent kinase 5 in the embryonic mouse nervous system. Development 119:1029-1040.

Tsai LH, Deialle I, Caviness Jr V, Chae T, Harlow E (1994) p35, a neuronal specific regulatory subunit of the cdk5 kinase. Nature 371:419-423

Vesely J, Havlicek L, Strnad M, Blow JJ, Donella-Deana A, Pinna L Letham DS, Kato J, Detivaud L, Leclerc S, Meijer L (1994) Inhibition of cyclin-dependent kinases by purine analogues. Eur J Biochem 224:771-786.

Vinje ML, Valø ET, Røste GK, Berg-Johnsen J (1999) Measured increase in intracellular $\mathrm{Ca} 2+$ during stimulated release of endogenous glutamate from human cerebrocortical synaptosomes. Brain Res 843:199-201.

Westenbroek RE, Hell JW, Warner C, Dubel SJ, Snutch TP, Catterall WA (1992) Biochemical properties and subcellular distribution of an N-type calcium channel $\alpha 1$ subunit. Neuron 9:1099-1115.

Westenbroek RE, Sakurai T, Elliott EM, Hell JW, Starr TVB, Snutch TP, Catterall WA (1995) Immunochemical identification and subcellular distribution of the $\alpha 1 \mathrm{~A}$ subunits of brain calcium channels. J Neurosci 15:6403-6418.

Wheeler DB, Randall A, Tsien RW (1996) Change in action potential duration alters reliance of excitatory synaptic transmission on multiple types of $\mathrm{Ca}^{2+}$ channels in rat hippocampus. J Neurosci 16:2226-2237.

Yan Z, Hsieh-Wilson L, Feng J, Tomizawa K, Allen PB, Feinberg AA, Nairn AC, Greengard P (1999) Protein phosphatase 1 modulation of neostriatal AMPA channels: regulation by DARPP-32 and spinophilin. Nat Neurosci 2:13-17.

Yokoyama CT, Sheng ZH, Catterall WA (1997) Phosphorylation of the synaptic protein interaction site on N-type calcium channels inhibits interactions with SNARE proteins. J Neurosci 17:6929-6938.

Zhong H, Yokoyama CT, Scheuer T, Catterall WA (1999) Reciprocal regulation of $\mathrm{P} / \mathrm{Q}$-type $\mathrm{Ca} 2+$ channels by SNAP-25, syntaxin and synaptotagmin. Nat Neurosci 2:939-941.

Zucker RS (1989) Short-term synaptic plasticity. Annu Rev Neurosci $12: 13-31$. 